\title{
Paleostress magnitude in a fold-thrust belt (External Hellenides, Greece): evidence from twinning in calcareous rocks
}

\author{
Department of Geology, University of Patras, GR-26500, Patras, Greece.E-mail: pxypolias@upatras.gr
}

\begin{abstract}
Based on twinned calcite in carbonate samples collected from the External Hellenides, we calculated paleostress magnitude and its across-strike variation into the Pindos Zone (PZ) and the Gavrovo Zone (GZ). These two zones are located west of the suture zone between the External and the Internal Hellenides. Paleostress magnitude is in the order of $110 \mathrm{MPa}$ close to the suture, dropping toward the foreland and reaching a value of $50 \mathrm{MPa}$ $80 \mathrm{~km}$ from the suture. The obtained distribution of paleostress levels in the External Hellenides resembles that recorded in other orogens, such as the Appalachian and Northern Pyrenean. The paleodepths of sampled carbonates during the initial stage of thrusting, which were estimated using the differential stress values, are structurally sensible. Comparing our results to available information on the evolution of paleostress magnitude with depth in compressional settings at the upper crust, we suggest that the mechanical behaviour of the cover thrust sheets of the External Hellenides is governed by the law of friction under nearly hydrostatic conditions. Based on this finding, as well as on published rheological data from rocks exposed at the deeper structural levels of the External Hellenides, a rheological profile was proposed. On this profile, brittle-ductile transition occurs at a depth of around 9-10 km, slightly deeper than the basal decollement of the External Hellenides.
\end{abstract}

\section{Introduction}

Numerous structural studies dealing with the geometric and kinematic evolution of fold-thrust belts suggest that frontal parts of a belt experience a single episode of deformation, whereas in the rear portions of a belt the deformation history involves multiple episodes (Wu, 1993; and references therein). From the geomechanical point of view, a given episode occurs if a threshold value of a rheological parameter(s) is exceeded (e.g., Handy et al., 2001). This fact implies that from the hinterland to the far foreland across a fold-thrust belt the value of a rheological parameter such as the differential stress $\left(\sigma_{1}-\sigma_{3}\right)$ should change significantly. For instance, studies in the Appalachian-Quachita mountain belt have documented an exponential decrease of paleostress magnitude $\left(\sigma_{1}-\sigma_{3}\right) 2,500 \mathrm{~km}$ away from the orogenic front (e.g., Van der Pluijm et al., 1997). Moreover, episodicity and localization of deformation in orogenic processes may be controlled by changes in rheological stratification of the upper continental crust, which is dependent on the distribution with depth of differential stress (e.g., Ranalli and Murphy, 1987; Handy et al., 2001).

In tectonically active belts, the magnitude of differential stress can be estimated using geophysical data or measured directly in the uppermost part of the lithosphere (e.g., Whitmarsh et al., 1991). Alternatively, in fossilized orogenic belts the paleostress magnitude inaccessible to direct measurement can be estimated by using paleopiezometers, which are mainly based on the dynamic recrystallization of calcite and quartz (e.g., Twiss, 1977; Weathers et al., 1979), and mechanical twinning in calcite (Jamison and Spang, 1976; Rowe and Rutter, 1990). Calcite-twin-based paleopiezometers have been extensively used to provide paleostress data from deformed carbonate rocks exposed in external portions of mountain belts (Ferrill, 1998 and references therein). Calcite twins mechanically at low differential stress ( $\approx 10 \mathrm{MPa}$; see Lacombe and Laurent, 1996), and is largely independent of temperature. Twinning is possible along three glide planes and calcite strain-hardens once twinned (Teufel, 1980). Because calcite strain-hardens after twinning, it is generally considered that twinned calcite mainly records strains related to the early stage of the development of fold-thrust belts (e.g. Kilsdonk and Wiltschko, 1988; Ferrill and Groshong, 1993).

The purpose of this study is to bring new information about the variation of differential stress across the inner parts of a fold-thrust belt (External Hellenides), and to define the way this rheological parameter evolves with depth in the brittle crust. For this purpose, paleo- stress magnitudes were estimated by applying to calcareous samples the paleopiezometric technique of Jamison and Spang (1976), which is based on mechanical twinning in calcite. Finally, we propose a possibly rheological profile in orogenic scale, and discuss the evolution of syn-orogenic basins, important for hydrocarbon reservoir exploitation in the area, as well as the effect of the orogenic-related rheology on the subsequent active rifting in the area.

\section{Geotectonic framework}

The External Hellenides are part of the Alpine orogenic belt, and represent a typical fold-thrust belt (e.g., Xypolias and Doutsos, 2000; Skourlis and Doutsos, 2003; Sotiropoulos et al., 2003). They are mainly composed of Meso- and Cenozoic sedimentary rocks deposited on a series of platforms (pre-Apulian, PA; and Gavrovo Zones, GZ; Figure 1a) and basins (Ionian, I; and Pindos Zone, PZ; Figure 1a). Mesozoic basins and platforms occupied the rifted eastern margin of the Apulia microcontinent, bordering the Pindos Ocean (e.g., Aubouin, 1959; Pe-Piper and Koukouvelas, 1992; Degnan and Robertson, 1998). The present disposition of the thrust sheets within the External Hellenides resulted from the Tertiary eastward subduction of the Apulian margin beneath Pelagonian (Internal Hellenides) microcontinent (Mountrakis, 1986; Doutsos et al., 1993, 


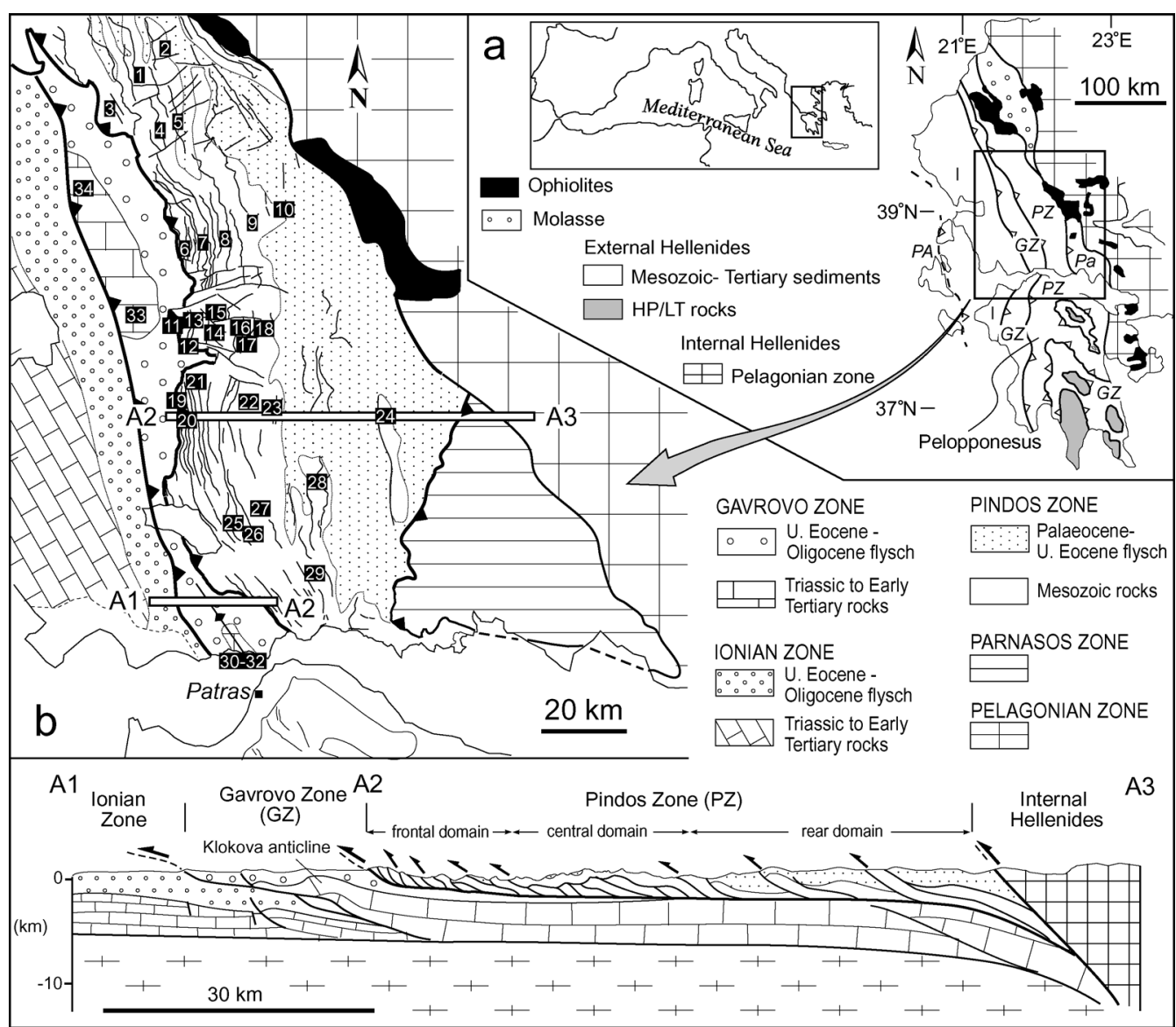

Figure 1 (a) Simplified tectonic map of the southwestern Hellenides showing the study area (box) and the major tectonostratigraphic units; PA: Pre-Apulia zone; I: Ionian zone; GZ: Tripolitza Zone; PZ: Pindos thrust belt; Pa: Parnassos zone. Inset shows the location of map in the Mediterranean region. (b) Geological map of the study area and a synthetic cross-section (A1-A3) illustrating the structure of the External Hellenides in the Greek mainland (modified after Skourlis and Doutsos, 2003; Sotiropoulos et al., 2003). The white numbers on black boxes indicate the locations of calcareous samples which were collected for calcite twin analysis.

1994). Collision began in Early Eocene times, and continued throughout the Tertiary with westward propagating intracontinental thrusting, following a piggy-back style (e.g., Underhill, 1989; Xуроlias and Doutsos, 2000).

Along-strike variations in both the original paleogeographic configuration and the rigidity of Apulian margin as well as the presence of transverse fault zones have strongly influenced the deformation history of the belt. The northwestern External Hellenides on the Greek mainland are mainly characterized by thin-skinned tectonics (Skourlis and Doutsos, 2003), while the southwestern Hellenides (Peloponnesus; Figure 1a) are characterized by both thin- and thickskinned tectonics involving intracontinental subduction within the Apulian margin, which is associated with the formation of high-pressure nappes (Doutsos et al., 2000; Xypolias and Koukouvelas, 2001).

In this study, we focus on the Greek mainland, carrying out sampling of calcareous rocks within the Pindos Zone (PZ) and the Gavrovo (GZ) Zone (Figure 1). The pre-orogenic sedimentary sequence of the PZ has an original thickness of $800-1000 \mathrm{~m}$ and mainly consists of deep-water carbonates, and siliciclastic and siliceous rocks that were accumulated along the western margin of the Pindos Ocean during Upper Triassic to Maastrictian times (e.g., Degnan and Robertson, 1998). They are overlain by a Paleocene-toUpper Eocene syn-orogenic clastic sequence (Faupl et al., 1998). This sequence indicates a thickness variation from $2,000-2,500 \mathrm{~m}$ in the rear parts of the $\mathrm{PZ}$ to $c .100 \mathrm{~m}$ in the frontal and central parts, implying a westward tapering of the sequence (Skourlis and Doutsos, 2003). The PZ is internally deformed by a system of west-verging thrust faults which 'sole-out' into a bedding-parallel floor thrust
(Pindos Thrust) located at the base of stratigraphic pile. Based on the across-strike changes in style of deformation, the $\mathrm{PZ}$ can be divided into three main structural domains: a frontal, a central and a rear domain (Xypolias and Doutsos, 2000; Skourlis and Doutsos, 2003). The frontal domain is occupied by a dense array of moderateto high-angle thrust faults (Figure $1 \mathrm{~b}$; A1-A3). The central domain is characterized by a duplex system bounded by a roof thrust and the Pindos Thrust as the floor thrust. More broadly spaced thrusts of ramp-flat geometry are dominant in the rear domain.

The PZ is tectonically emplaced via the Pindos Thrust over the GZ to the west (Figure 1b; A1-A3). The GZ constitutes a c. 3,000 m thick shallow-water carbonate sequence of Mesozoic age, and is considered to represent the shelf sediments of the Apulian passive continental margin which passed gradually into the deepwater sedimentary sequence of Pindos to the east (Fleury, 1980). On the top of the Mesozoic carbonate rocks of the GZ have unconformably accumulated c. 1,800 m thick syn-orogenic clastics of Upper Eocene to Early Miocene age (e.g., Richter, 1976). The GZ is a mechanically strong and rigid carbonate sequence which generally is internally deformed by very broad spaced thrust faults (Xypolias and Doutsos, 2000; Sotiropoulos et al., 2003).

\section{Methods and materials}

Thirty-four oriented samples of packstone and wackestone were collected for the purposes of this study. Twenty-two samples were collected from the Cretaceous limestones of the PZ, seven from the upper Triassic limestones of the PZ, and five from the Cretaceous limestones of the GZ. All samples were collected away from zones of intense local deformation (e.g. fold hinges and mesoscopic faults) in order to reflect regional strain patterns. Moreover, they were chosen with a wide spatial distribution (across-strike width $c .80 \mathrm{~km}$, along-strike length $c .150 \mathrm{~km}$; Figure $1 \mathrm{~b}$ ) to represent the regional deformation in the area. One thin section oriented parallel to transport direction (approximately E-W) and perpendicular to bedding was cut from each sample. In all samples, the calcite grains are characterized by thin twins (twin thickness $<5 \mu \mathrm{m}$ ), which are indicative of calcite deformed below $200^{\circ} \mathrm{C}$ (Ferrill, 1998).

To obtain differential stress magnitude from our samples, we used the calcite-twin-based technique of Jamison and Spang (1976), because it yields the best estimations for limestones deformed at very low temperature (Ferrill, 1998). Rowe and Rutter (1990) have proposed another method, which is based on calcite-twin density (twins/mm), but it greatly overestimates the differential stress magnitude in the thin-twinning regime (Ferrill, 1998). The adopted technique (Jamison and Spang, 1976) relates the differential stress $\left(\Delta \sigma=\sigma_{1}-\sigma_{3}\right)$ to a critical resolved shear stress $(t c)$ necessary to pro- 
duce twin gliding, and a resolved shear stress coefficient $(S)$ by the equation:

$$
\Delta \sigma=t c / S
$$

The resolved shear stress coefficient $(S)$ can be estimated graphically if the percentage of twinned calcite grains containing one, two or three twin sets in a specific sample is known (Jamison and Spang 1976; their fig. 4). The critical resolved shear stress (tc) is experimentally determined at $10 \mathrm{MPa}$. Critical limitation of the method is the $t c$ value for twinning, which was originally controversial (see review of Burkhard, 1993). However, the $10 \mathrm{MPa}$ value has been convincingly argued to be correct by Lacombe and Laurent (1996). The methods also require samples that include randomly orientated coarse-grained calcite and suffered relatively little (twin strain less than $4 \%$ ) and homogeneous strain.

A minimum of around 60 coarse-grained calcites were used in each sample to apply the paleopiezometer of Jamison and Spang (1976). Table 1 lists the percentage of calcite grains, with one, two or three twin sets in each analyzed sample, as well as the estimated differential stress values. Furthermore, the mean twin density (twins $/ \mathrm{mm}$ ) and the mean twin thickness $(\mu \mathrm{m})$ were also calculated. The 'mean twin thickness' for a sample is determined by first calculating the average twin thickness for each twin set (twin set average) and then averaging the twin-set averages for the sample. Noted that the thickness is measured as the perpendicular distance between boundaries with the twins rotated to vertical on a universal stage. The twin density (twins/mm) for each twin set is calculated by dividing the number of twins in a set by the width of the host grain measured perpendicular to the twins. The 'mean twin density' for a sample is calculated by averaging the twin-set averages for all twin sets measured in the sample (see also Ferrill et al., 2004 for methodogy). Calcite twin density and twin thickness are directly correlated with twin strain (Ferrill et al., 2004) and therefore used to measure the strain levels in our samples.

Table 1 Calcite twin data and paleostress estimates for calcareous samples from the Pindos and the Tripolitza Zones.

\begin{tabular}{|c|c|c|c|c|c|c|c|c|c|c|}
\hline \multirow{2}{*}{ No } & \multirow{2}{*}{ Lithology } & \multirow{2}{*}{$\begin{array}{l}\text { Twin } \\
\text { Density } \\
\text { (\#/mm) }\end{array}$} & \multirow{2}{*}{$\begin{array}{l}\text { Twin } \\
\text { thickness } \\
(\mu \mathrm{m})\end{array}$} & \multicolumn{3}{|c|}{ Twin sets (\%) } & \multicolumn{4}{|c|}{ Differential stress (MPa) } \\
\hline & & & & set1 & set2 & $\operatorname{set} 3$ & $\Delta \sigma(I$ & $\Delta 6$ & $\Delta 6$ & selected \\
\hline \multicolumn{11}{|c|}{ PINDOS ZONE } \\
\hline 1 & Cret. & 45 & 0.48 & 74.0 & 19.0 & - & 81 & 70 & - & 70 \\
\hline 2 & Cret. & 46 & 0.54 & 75.5 & 22.5 & - & 90 & 85 & - & 85 \\
\hline 3 & Trias. & 102 & 0.55 & 72.5 & 23.5 & - & 73 & 89 & - & 89 \\
\hline 4 & Trias. & 75 & 0.42 & 74.0 & 20.0 & - & 81 & 73 & - & 73 \\
\hline 5 & Cret. & 75 & 0.35 & 70.0 & 25.0 & 0.85 & 63 & 100 & 86 & 86 \\
\hline 6 & Trias. & 97 & 0.58 & 73.0 & 25.5 & - & 75 & 104 & - & 104 \\
\hline 7 & Cret. & 48 & 0.46 & 71.0 & 21.0 & - & 66 & 78 & - & 78 \\
\hline 8 & Cret. & 66 & 0.61 & 76.0 & 20.0 & - & 95 & 73 & - & 73 \\
\hline 9 & Cret. & 78 & 0.52 & 77.0 & 25.0 & - & 105 & 100 & - & 100 \\
\hline 10 & Trias. & 54 & 0.75 & 72.0 & 23.0 & 2.0 & 70 & 87 & 96 & 96 \\
\hline 11 & Cret. & 72 & 0.45 & 72.0 & 19.0 & - & 70 & 70 & - & 70 \\
\hline 12 & Cret. & 60 & 0.30 & 74.5 & 21.0 & - & 84 & 78 & - & 78 \\
\hline 13 & Cret. & 50 & 0.68 & 69.0 & 16.0 & - & 60 & 63 & - & 63 \\
\hline 14 & Cret. & 51 & 0.38 & 74.5 & 21.0 & - & 84 & 78 & - & 78 \\
\hline 15 & Cret. & 48 & 0.46 & 72.0 & 21.0 & - & 70 & 78 & - & 78 \\
\hline 16 & Cret. & 42 & 0.42 & 67.0 & 24.0 & - & 58 & 92 & - & 92 \\
\hline 17 & Cret. & 61 & 0.68 & 73.0 & 24.0 & - & 75 & 92 & - & 92 \\
\hline 18 & Cret. & 80 & 0.42 & 69.0 & 21.3 & - & 60 & 79 & - & 79 \\
\hline 19 & Cret. & 98 & 0.65 & 75.0 & 27.0 & - & 87 & 113 & - & 113 \\
\hline 20 & Trias. & 109 & 0.76 & 76.0 & 25.5 & - & 95 & 104 & - & 104 \\
\hline 21 & Trias. & 115 & 0.48 & 70.0 & 24.0 & - & 63 & 95 & - & 95 \\
\hline 22 & Cret. & 50 & 0.60 & 76.0 & 26.0 & 2.0 & 95 & 108 & 96 & 96 \\
\hline 23 & Trias. & 75 & 0.51 & 76.5 & 22.5 & - & 100 & 85 & - & 85 \\
\hline 24 & Cret. & 62 & 0.54 & 80.0 & 31.0 & 4.0 & 166 & 166 & 108 & 108 \\
\hline 25 & Cret. & 41 & 0.42 & 78.0 & 21.5 & - & 128 & 76 & - & 76 \\
\hline 26 & Cret. & 37 & 0.47 & 76.0 & 23.0 & - & 95 & 87 & - & 87 \\
\hline 27 & Cret. & 62 & 0.47 & 77.0 & 28.0 & 2.5 & 105 & 127 & 100 & 100 \\
\hline 28 & Cret. & 58 & 0.35 & 78.0 & 27.0 & 3.2 & 128 & 113 & 111 & 111 \\
\hline 29 & Cret. & 64 & 0.73 & 70.5 & 21.0 & - & 64 & 78 & - & 78 \\
\hline \multicolumn{11}{|c|}{ GAVROVO ZONE } \\
\hline 30 & Cret. & 46 & 0.57 & 61.0 & 7.5 & - & 45 & 47 & - & 47 \\
\hline 31 & Cret. & 51 & 0.50 & 65.0 & 15.0 & - & 52 & 60 & - & 60 \\
\hline 32 & Cret. & 39 & 0.48 & 70.0 & 11.0 & - & 63 & 53 & - & 53 \\
\hline 33 & Cret. & 42 & 0.68 & 67.0 & 14.0 & - & 58 & 59 & - & 59 \\
\hline 34 & Cret. & 35 & 0.60 & 62.0 & 10.0 & - & 46 & 52 & - & 52 \\
\hline
\end{tabular}

\section{Across-strike variation in paleostress magnitude}

Point counts of 29 samples from the PZ indicated that c. $70-80 \%$ of the calcite grains contain at least one set of twins, and c. $20-30 \%$ of the grains contain two or more sets (Table 1). Calcite grains exhibiting three twin sets were found in six samples. In these samples, the percentage of grains with three sets of twins ranges from $1 \%$ to $4 \%$. Analysis of samples from the GZ revealed that twinned crystals display at least one (c. 60-70\%) and occasionally two sets (7.5-15\%) of twins. The measured frequency of calcite grains twinned by two or three sets yield differential stress magnitudes ranging from 63 to $113 \mathrm{MPa}$ for the PZ and 47 to $60 \mathrm{MPa}$ for the GZ (Table 1).

In order to examine the across-strike variation of paleostress magnitude in both PZ and GZ, we constructed a graph showing the distribution of differential stress vs. distance of samples from the Pindos front (Figure 2a). The structural distance was measured parallel to the transport direction of the belt (approximately E-W). The results from the $\mathrm{PZ}$ indicate a systematic reduction of differential stress as the Pindos front is approached from the east. In more detail, the $\Delta \sigma$ value decreased from $c .110 \mathrm{MPa}$ at a projected distance of around $50 \mathrm{~km}$ to $c .70 \mathrm{MPa}$ at a distance of $5 \mathrm{~km}$ from the Pindos front. However, five samples $(3,6,19,20,21)$ collected from the outermost part of the frontal domain imply a remarkable increase in differential stress magnitudes from 70 to $113 \mathrm{MPa}$ within a distance interval of around $4 \mathrm{~km}$ (Figure 2a). Based on the empirical diagram suggested by Ferrill et al. (2004), correlating the ratio of twinned to untwinned calcite crystals (mean twin thickness $\times$ mean twin density) with the twin strain, it seems that all these five samples $(3,6,19$, 20,21 ) are characterized by calcite twin strain more than $4 \%$ (Figure $2 b$ ). Given that the applied calcite-twin method tends to overestimate stress magnitude for twin strain higher than $4 \%$ (e.g. Jamison and Spang, 1976; Burkhard, 1993), it is reasonable to assume that data from these five samples do not reflect a reliable increase in differential stress magnitude. Based on field evidence, it seems that the recorded high twin strain within these samples resulted from penetrative and strong deformation due to a dense thrust system in the frontal domain of the PZ (Figure 1b). Moreover, it is noteworthy that samples collected from the same projected distance record nearly the same stress levels (e.g., 1, 5, 15 and 2, 18, 22; Table 1, Figure 2a), implying negligible along-strike variation of paleostrss magnitude in the PZ. With the exception of the outermost part of the frontal domain in the PZ (0-4 km; Figure 2a), the observed along-strike variation in differential stress is on the order of $15 \mathrm{MPa}$.

Distribution of the obtained $\Delta \sigma$ values within the GZ seems to follow the above-described tendency of westward reduction in differential stress (Figure 2a). The paleostress magnitude is $c .60 \mathrm{MPa}$ close to the Pindos front (Figure 2a; sample 33 at a distance of $4 \mathrm{~km}$ ) and decreases slightly toward the west, reaching a value of around 50 $\mathrm{MPa}$ at a distance of $16 \mathrm{~km}$.

\section{Paleodepth of deformation}

Several interpretations of the temporal relationship between the calcite twinning process and the evolution of thrust belts suggest that mechanical twinning of calcite mainly occurs during the early stages of tectonic history and is primarily achieved by layer-parallel shortening (e.g. Kilsdonk and Wiltschko, 1988; Ferrill and Groshong, 1993). Therefore, the differential stress $\left(\sigma_{1}-\sigma_{3}\right)$ magnitudes recorded in this study, which are inferred from calcite twinning, seem to reflect paleostress during the early stages of folding and thrusting within PZ and GZ. A recent study of the External Hellenides (Kokkalas et al., 2003) has demonstrated that during the initial stages of folding the maximum principal stress axis $\sigma_{1}$ was subhorizontal and parallel to the dip direction of bedding $(\mathrm{E}-\mathrm{W})$, the intermediate axis $\sigma_{2}$ was nearly vertical and perpendicular to bedding, while the minimum $\sigma_{3}$ 


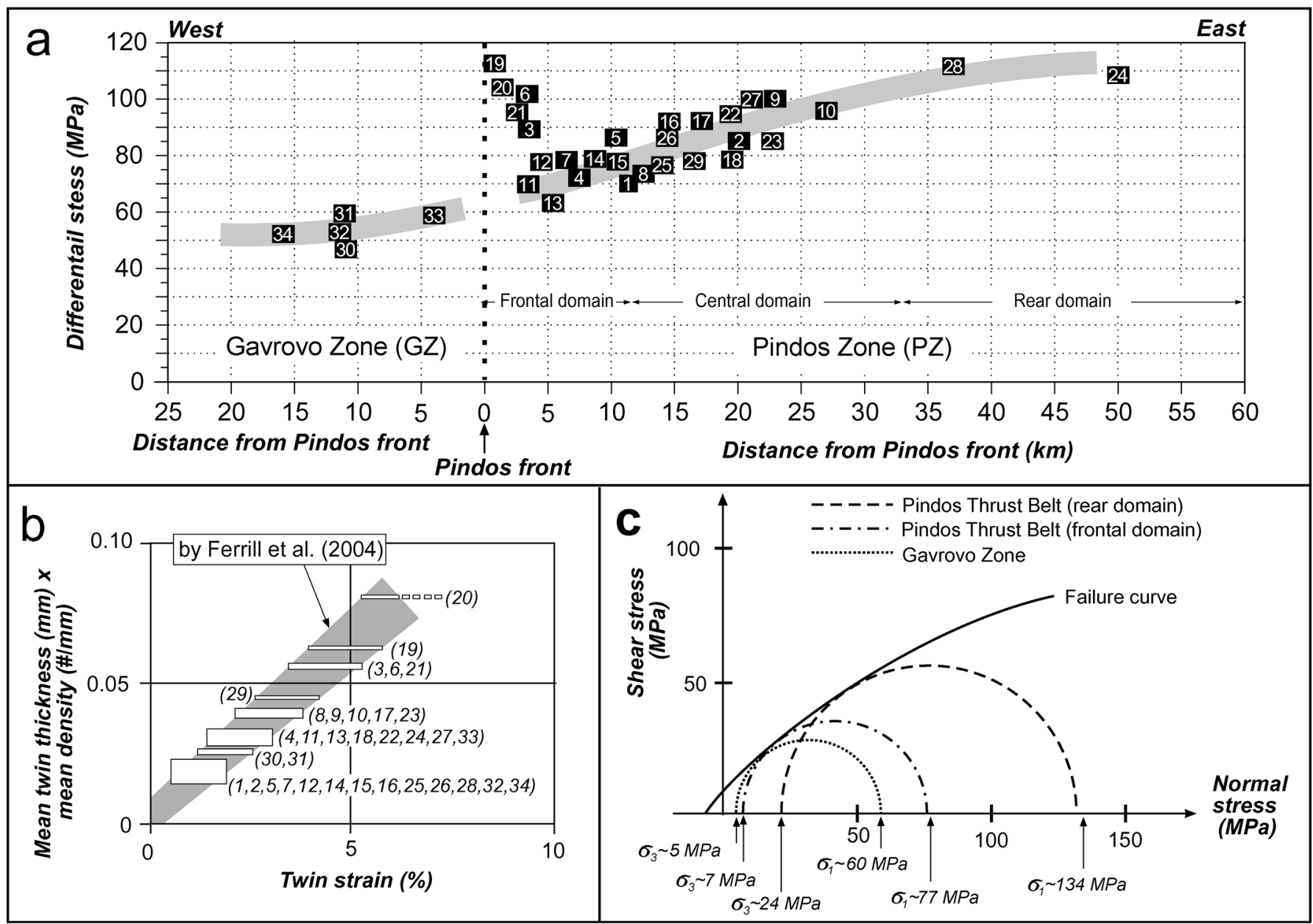

Figure 2 (a) Diagram showing the variation of the differential stress values along a traverse parallel to the transport direction. (b) Results on twin thickness and density were projected on a graph correlating the ratio of twinned to untwinned calcite crystal (mean twin thickness $x$ mean twin density) with the twin strain. Only five samples $(3,6,19,20,21)$ are characterized by calcite twin strain more than 4\%. (c) Mohr circles construction for the estimation of $\sigma_{1}$ and $\sigma_{3}$ during the early stage of thrusting in the External Hellenides.

was parallel to fold axis (N-S). In addition, the above study has shown that in this stress pattern the magnitude of principal stress axis $\sigma_{2}$ and $\sigma_{3}$ is equal. For an analogue stress regime in Taiwan fold-thrust belt, Lacombe (2001) suggested that during the early stage of thrusting the $\sigma_{2}\left(\sim \sigma_{3}\right)$ value should equal the effective weight of sediments $\left(\sigma_{v}\right.$, normal stress) over the sampled rocks.

The $\sigma_{3}\left(\sim \sigma_{2}\right)$ value can be evaluated using the Coulomb failure criterion for intact rocks based on experimental deformation in limestones (see Lacombe and Laurent, 1992). For instance, constructing a Mohr circle of diameter $110 \mathrm{MPa}$, which corresponds to the estimated differential stress magnitude $\left(\sigma_{1}-\sigma_{3}\right)$ for the rear domain of the PZ (Figure 2a), and fitting it to the failure curve, we obtain $\sigma_{3} \sim 24 \mathrm{MPa}$ (Figure 2c). Following the same procedure for the rocks collected from the frontal domain of the PZ (average $\Delta \sigma=70$ $\mathrm{MPa}$; Figure 2a) and the GZ (average $\Delta \sigma=55 \mathrm{MPa}$; Figure 2a) we estimate $\sigma_{3} \sim 7 \mathrm{MPa}$ and $5 \mathrm{MPa}$, respectively (Figure $2 \mathrm{c}$ ).

Equalling the magnitude of the calculated vertical stress $\sigma_{2} \sim \sigma_{3}$ with the effective weight of overburden $\sigma_{\mathrm{v}}$, then the thickness $(\mathrm{z})$ of sediments over the sampled calcareous rocks can be estimated by using the following relation (e.g., Sibson, 1998): $\sigma_{\mathrm{v}}=\rho \mathrm{gz}(1-\lambda)$, where $\rho$ is an average rock density $\left(2600 \mathrm{kgr} / \mathrm{m}^{3}\right)$, g is the gravitational acceleration $\left(9.8 \mathrm{~m} / \mathrm{sec}^{2}\right)$ and $\lambda$ is the pore-fluid factor (pore fluid pressure/lithostatic pressure). The value of pore fluid factor $(\lambda)$ is difficult to prove, however, as there is no evidence in the form of hydrofracturing or other features (e.g. Kokkalas et al., 2003) to suggest a near lithostatic $(\lambda=1)$ fluid pressure within the studied rocks. Therefore, assuming for the PZ a pore-fluid pressure close to hydrostatic $(0.4<\lambda<0.7)$, which is a rational magnitude for a fold-thrust belt (e.g. Davis et al., 1983), the above equation reveals that the Cre- taceous limestone was buried under 2,400 $( \pm 800) \mathrm{m}$ of overburden (syn-orogenic clastics) in the rear domain and $600( \pm 300) \mathrm{m}$ in the frontal domain of the belt during the early stages of thrusting. For a similar pore-fluid factor, the above equation consequently implies a cover thickness of about $500( \pm 150)$ m over the sampled Cretaceous calcareous rocks of the GZ.

The above paleodepth estimates within the PZ are consistent with stratigraphic data suggesting a decrease in thickness of synorogenic sequence from $c .2,500 \mathrm{~m}$ at the rear domain to $c .100 \mathrm{~m}$ at the frontal part of the belt. The observed consistency implies that the accumulation of syn-orogenic clastics on top of Mesozoic rocks predates or was synchronous with the early stages of thrusting within the PZ. The difference between the estimated $(c .600 \mathrm{~m})$ and the stratigraphically-recorded thickness $(c .100 \mathrm{~m})$ of this sequence at the frontal domain of the belt possibly indicates erosion of the sequence at the toe during later stages of deformation.

Regarding the GZ, it seems that there is a significant difference between the estimated $(c .500 \mathrm{~m})$ and the stratigraphically-recorded thickness $(c .1,800 \mathrm{~m})$ of syn-orogenic clastic sequence. Our data imply that only a minor amount of clastics was deposited over the Mesozoic carbonate at the early stages of thrusting within the GZ. Therefore, it can be assumed that the remaining volume of clastics accumulated during an advancing stage of thrusting. This hypothesis is in agreement with previous studies in the area, emphasizing that rocks of the Klokova anticline (Figure 1b; A1-A3) were exposed at the Earth's surface during the deposition of the lower stratigraphic horizons of the syn-orogenic sediments, which have a thickness of about $300 \mathrm{~m}$ (Sotiropoulos et al., 2003). Given that our samples were collected from the Klokova anticline (samples 30-32; Figure 1b) and 
structural equivalent areas in the north (samples 33, 34; Figure 1a), we consider that our assumption is reliable.

\section{Discussion}

\section{Comparison with other orogens}

Differential stress magnitude, as estimated by twinned calcite in carbonate rocks of the External Hellenides, steadily decreases from $\sim 110 \mathrm{MPa}$ at the rear domain of the PZ to $\sim 50 \mathrm{MPa}$ at the GZ (Figures 1b, 2a). Therefore, the observed foreland-ward (westward) reduction in differential stress is in the order of $\sim 60 \mathrm{MPa}$, and is achieved within a distance of $\sim 80 \mathrm{~km}$ away from the plate boundary zone between the Apulian and Pelagonian microcontinents (Figures $1 \mathrm{~b}, 2 \mathrm{a})$. The paleostress distribution obtained in the present study for the External Hellenides appears to be comparable with pattern within other orogens. For instance, orogenic stress data inferred from twinned calcite in limestones in the foreland domains of both the Appalachian and Sevier orogens suggest that differential stress magnitude rapidly decreases from $\sim 100 \mathrm{MPa}$ at the orogenic front to $\sim 45 \mathrm{MPa}$ at $100 \mathrm{~km}$ inland (e.g., Van der Pluijm et al., 1997). Generally, the results of our work also fit the logarithmic relation $(\Delta \sigma=$ $-10 \ln \mathrm{D}+92$ ) suggested for the above-mentioned orogens and correlate distance (D) from the orogenic front with differential stress magnitude $(\Delta \sigma)$. Furthermore, differential stress in the External Hellenides resembles data from the South-Aquitaine Basin, suggesting a similar drop of differential stress magnitude from the Pyrenean orogenic front toward the foreland (Rocher et al., 2000).

Recently, Lacombe (2001) emphasized that the overall decrease in differential stress from the hinterland to the foreland not only reflects tectonic stress attenuation away from a plate boundary but also suggests a major control by the depth of deformation. Compilation of stress data from various orogenic systems (Figure 3a) implies that sedimentary rocks in fold-thrust domains are deformed at depths between $300 \mathrm{~m}$ and $4-5 \mathrm{~km}$ under differential stress values between 30 and $140 \mathrm{MPa}$. Moreover, these data define two stress-depth gradients (gradients A and B in Figure 3a) of natural differential stress values at depth. Examining the obtained paleostress and paleodepth val- ues of this study with respect to two stress-depth gradients in Figure 3a, it seems that both the PZ and the GZ follow the gradient B, which is consistent with frictional behaviour of the upper crust under nearly hydrostatic conditions obeying the law of friction (e.g. Brace and Kohlstedt, 1980). This finding indicates that the assumption for nearly hydrostatic fluid pressure in the $\mathrm{PZ}$ and the GZ is reliable.

\section{Stress-depth profile}

Based on the above-mentioned comparison, we suggest that during the development of the External Hellenides the mechanical strength of the belt was governed by the law of friction for the thrust regime with friction coefficient of around 0.75 under nearly hydrostatic conditions $(\Delta s=3 \rho g z 0.6$; Sibson, 1974). This fact, in combination with rheological data derived from the lower structural levels of the External Hellenides (Xypolias, 2001; Xypolias and Koukouvelas, 2001) in northern Peloponnesus area (Figure 1a), enables us to construct a stress-depth profile showing the rheological stratification in the Hellenides (Figure 3b). Deformation of Phyllite-Quartzite Unit (HP/LT rocks in Figure 1a) underlying the GZ in Peloponnesus is dominated by dislocation creep (Xypolias and Koukouvelas, 2001). Thus, its mechanical behaviour is governed by a non-linear viscous law: $\Delta \sigma=(\varepsilon / \mathrm{A})^{1 / n} \exp (\mathrm{Q} / \mathrm{nRT})$, where $\varepsilon$ denotes the strain rate in $\mathrm{s}^{-1}, \mathrm{~A}$ is a rock-specific parameter; $\mathrm{n}$ is the power-law exponent, $\mathrm{Q}$ is the activation energy, $\mathrm{R}$ is the gas constant, and $\mathrm{T}$ is the absolute temperature (Ranalli and Murphy, 1987, and references therein). In the proposed profile (Figure 3b), the viscous-creep strength of the rocks is based on the law of flow for dislocation creep of quartz derived by Paterson and Luan (1990), assuming strain rates of $10^{-13}$ and $10^{-14} \mathrm{~s}^{-1}$ (e.g., Xypolias, 2001). A geothermal gradient of $20^{\circ} \mathrm{C} / \mathrm{km}$, which is reasonable for a convergent setting, is also used, adopting temperature and pressure estimates for metamorphic rocks of the northern Peloponnesus $\left(375 \pm 25^{\circ} \mathrm{C}, 5 \mathrm{kbar}\right.$; Katagas et al., 1991).

On rheological profiles, the change from brittle frictional to dislocation creep deformation represents the brittle-ductile transition (Ranalli and Murphy, 1987). As illustrated in Figure 3b, this transition for the study area occurs at a shallow depth around 9-10 km,

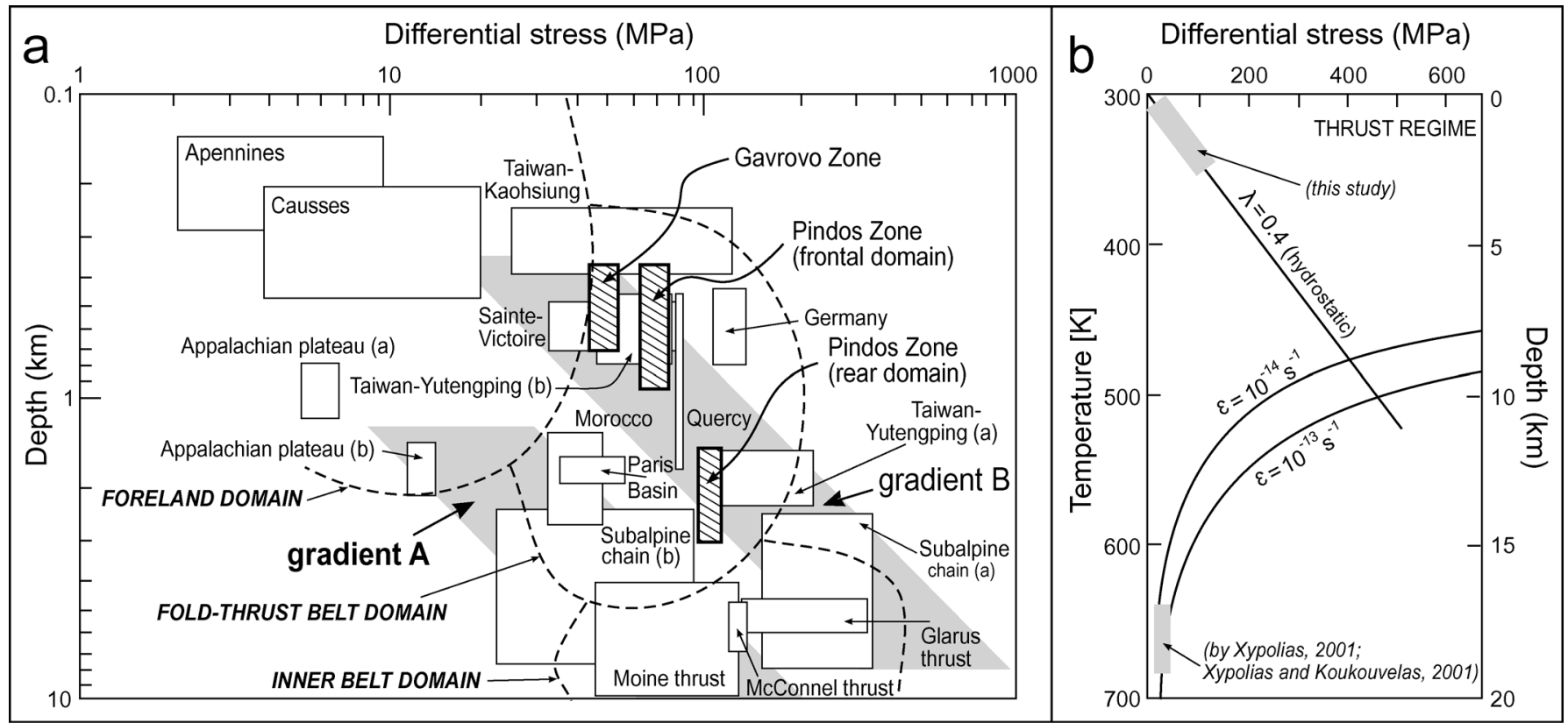

Figure 3 (a) Differential stress vs. depth (log-log) diagram integrating available information on the stress levels in compressional settings (adapted by Lacombe, 2001). Results of this study fit with stress-depth gradient B (right shaded zone) which is consistent with frictional behaviour of the upper crust under nearly hydrostatic conditions obeying friction law. (b) Suggested rheological stratification (differential stress vs. depth) of the upper crust of External Hellenides during orogenic movements. Straight line indicate frictional strength of the brittle crust in a thrust regime (calculated after Sibson, 1974); curved lines show viscous strength at strain rates ( $\varepsilon$ ) suggested for rocks exposed on deeper structural levels of External Hellenides (e.g., Xypolias and Koukouvelas, 2001) and based on dislocation creep of quartz (after data of Paterson and Luan, 1990). Shades indicate results of this study as well as previous rheological results in the area. 
dependent on strain rate. Similar depths for brittle-ductile transition have also been recorded in other orogens like the mountain range of the central Iberian Peninsula (Tejero and Ruiz, 2002). Taking into account that the PZ and the GZ in central Greece have a combined structural thickness of 6-8 km (Figure 1b, A1-A3), it seems that the basal decollement of the External Hellenides, at least at the rear part of the belt, is located close to the brittle-ductile transition. Recent seismological data from the southern part of the study area (Latorre et al., 2004; their fig. 16d) indicate a large-scale sharp vertical increase of seismic velocities at a depth of $c .7 \mathrm{~km}$, which correspond to the basal decollement, and a strong concentration of seismicity, related to active rifting in the area, at a depth of $c .9 \mathrm{~km}$. On the base of both our rheological profile and the above geophysical findings, we argue that the brittle-ductile transition was located at a depth of around $9-10 \mathrm{~km}$ during compressional movements from the Eocene to the Middle Miocene, and remained almost at the same depth until the present day. Based on this conclusion, we suggest that some features of the Alpine orogeny in Greece, like the brittle-ductile depth, control the present-day extension, at least in the study area.

\section{Concluding remarks}

Determination of paleostress magnitude based on twinned calcite in carbonate rocks of the Pindos (PZ) and Gavrovo (GZ) Zones of the External Hellenides shows a systematic decrease of differential stress $\left(\sigma_{1}-\sigma_{3}\right)$ from $\sim 110 \mathrm{MPa}$ at the rear part of the belt close to the collision zone between the Apulian and Pelagonian microcontinents to $\sim 50 \mathrm{MPa}$ at $80 \mathrm{~km}$ inland. The levels of paleostress magnitude within the External Hellenides and the obtained drop of this quantity toward the foreland are comparable with paleostress distribution in the front of other orogens such as the Appalachian and the Northern Pyrenean.

Estimates of the paleodepth of the sampled carbonates during the initial stage of thrusting revealed a variation in thickness of the overburden syn-orogenic clastics from $c .2,400 \mathrm{~m}$ in the rear domain of the PZ to $c .600 \mathrm{~m}$ in the frontal domain, indicating a westward tapering of the sequence similar to that recorded by stratigraphic data. This fact possibly indicates that the accumulation of synorogenic clastics on top of Mesozoic rocks predates or was synchronous with the early stages of thrusting within the PZ. In the case of the GZ, a significant difference between the estimated paleodepth $(c .500 \mathrm{~m})$ and the stratigraphically recorded present thickness (c. $1,800 \mathrm{~m}$ ) of the syn-orogenic clastic sequence is recognized. This difference enables us to assume that the major volume of synorogenic clastics accumulated over the Mesozoic carbonates of the GZ during an advancing stage of thrusting. This interpretation is compatible with published works on the area. Therefore, our application implies that paleodepth estimates are structurally sensible and particularly useful for retrieving information for the evolution of syn-orogenic basins.

Comparing our results to available information on the distribution of paleostress magnitude with depth in compressional settings at the upper crust, it appears that the mechanical strength of the cover thrust sheets of the External Hellenides is governed by the law of friction under nearly hydrostatic conditions. Based on this finding and published rheological data for the mechanical behaviour of the deeper structural levels of the External Hellenides, a rheological profile is proposed. According to this profile, the brittle-ductile transition occurs at a depth of around 9-10 km, slightly deeper than the basal decollement of the External Hellenides in central Greece, which are located at a depth of 6-8 $\mathrm{km}$.

\section{Acknowledgements}

Partial financial support of the field work for this study provided by Enterprise Oil Ltd, Hellenic Petroleum, M.O.L. and ARCO (Grants No. 18631, 18632) is gratefully acknowledged. Thanks are due to Kostas Skourlis for his assistance and generosity in this field. Constructive comments by journal's referees are also acknowledged.

\section{References}

Aubouin, J., 1959, Contribution a l'étude géologique de la Grèce septentrionale: le confins de l'Epire et de la Thessalie: Ann. Geol. Pays Hellen., v. 10, pp. 1-484.

Brace, W.F. and Kohlstedt, D.L., 1980, Limits on lithospheric stress imposed by laboratory experiments: J. Geophys. Res., v. 85, pp. 6248-6252.

Burkhard, M., 1993, Calcite twins, their geometry, appearance and significance as stress-strain markers and indicators of tectonic regime: a review: J. Struct. Geol., v. 15, pp. 351-368.

Davis, D., Suppe, J. and Dahlen, F.A., 1983, Mechanics of fold-and-thrust belts and accretionary wedges: J. Geophys. Res., v. 88, pp. 1153-1172.

Degnan, P.J. and Robertson, A.H.F., 1998, Mesozoic-early Tertiary passive margin evolution of the Pindos ocean (NW Peloponnese, Greece): Sediment. Geol. v. 117, pp. 33-70.

Doutsos, T., Piper, G., Boronkay, K. and Koukouvelas, I., 1993, Kinematics of the Central Hellenides: Tectonics, v. 12, pp. 936-953.

Doutsos, T., Koukouvelas, I., Zelilidis, A and Kontopoulos, N., 1994, Intracontinental wedging and post-orogenic collapse in the Mesohellenic Trough: Geol. Rundsch., v. 83, pp. 257-275.

Doutsos, T., Koukouvelas, I., Poulimenos, G., Kokkalas, S., Xypolias, P. and Skourlis, K., 2000, An exhumation model of the south Peloponnesus, Greece: Int. J. Earth Sciences, v. 89, pp. 350-365.

Faupl, P., Pavlopoulos, A. and Migiros, G., 1998, On the provenance of flysch deposits in the External Hellenides of mainland Greece: results from heavy mineral studies: Geol. Mag., v. 135, pp. 421-442.

Ferrill, D.A., 1998, Critical re-evaluation of differential stress estimates from calcite twins in coarse-grained limestone: Tectonophysics, v. 285, pp. 77-86.

Ferrill, D.A. and Groshong, R.H., 1993, Deformation conditions in the northern Subalpine Chain, France, estimated from deformation modes in coarsegrained limestone. J. Struct. Geol., v. 15, pp. 995-1006.

Ferrill, D., Morris, A.P., Evans, M.A., Burkhard, M., Groshong, R.H. and Onasch, C.M., 2004, Calcite twin morphology: a low-temperature deformation geothermometer: J. Struct. Geol., v. 26, pp. 1521-1529.

Fleury, J., 1980, Les zones de Gavrovo - Tripolitsa et du Pinde - Olonos (Grèce continentale et Pèloponnése du Nord). Évolution d'une plateforme et d'un bassin dans leur carde alpin: Soc. Géol. Nord, Publ. 4, pp. 1-651.

Handy, M.R., Braun, J., Brown, M., Kukowski, N., Paterson, M.S., Schmid, S.M., Stöckhert, B., Stüwe, K., Thompson, A.B., Wosnitza, E., 2001, Rheology and geodynamic modelling: the next step forward: Int. J. Earth Sciences, v. 90, pp. 149-156.

Jamison, W.R. and Spang, J.H., 1976, Use of calcite twin lamellae to infer differential stress: Geol. Soc. Am. Bull, v. 87, pp. 868-872

Katagas, C., Tsolis-Katagas, P. and Baltatzis, E., 1991, Chemical mineralogy and illite crystallinity in low grade metasediments, Zarouchla Group, Northern Peloponnesus, Greece: Mineral. Petrol., v. 44, pp. 57-71.

Kilsdonk, B. and Wiltschko, D.V., 1988, Deformation mechanism in the southern ramp region of the Pine Mountain block Tennessee: Geol. Soc. Am. Bull., v. 100 , pp. 653-664.

Kokkalas, S., Xypolias, P., Koukouvelas, I. and Doutsos, T., 2003, Relationships between folding and fracturing: Examples from the Rhenohercynian Zone (Germany) and the external Hellenides (Greece): Geol. Carpathica, v.54, pp. 153-162.

Lacombe, O., 2001, Paleostress magnitudes associated with development of mountain belts: Insights from tectonic analyses of calcite twins in the Taiwan Foothills: Tectonics, v. 20, pp. 834-849.

Lacombe, O. and Laurent, P., 1992, Determination of principal stress magnitudes using calcite twins and rock mechanics data: Tectonophysics, v. 202, pp. 83 93.

Lacombe, O. and Laurent, P., 1996, Determination of deviatoric stress tensors based on inversion of calcite twin data from experimentally deformed monophase samples: preliminary results: Tectonophysics, v. 255, pp. 189202.

Latorre, D., Virieux, J., Monfret, T., Monteiller, V., Vanorio, T., Got, J.-L. and Lyon-Caen, H., 2004, A seismic tomography of Aigion area (Gulf of Corinth, Greece) from the 1991 data set: Geophys. J. Int., v. 159, pp. 1013-1031.

Mountrakis, D., 1986, The Pelagonian zone in Greece: A polyphase-deformed fragment of the Cimmerian continent and its role in the geotectonic evolution of the eastern Mediterranean: J. Geol., v. 94, pp. 335-347.

Paterson, M.S. and Luan, F.C., 1990, Quartzite rheology under geological conditions, in Knipe, R.J. and Rutter, E.H., eds, Deformation Mechanisms, Rheology and Tectonics: Geol. Soc., London Spec. Publ., no 54, pp. 299-307.

Pe-Piper, G. and Koukouvelas, I., 1992, Petrology, geochemistry and regional significance of igneous clasts in Parnassos flysch, Amphissa area, Greece. N. Jahrb. Min. Abh., v. 164, pp. 94-112.

Ranalli, G. and Murphy, D.C., 1987, Rheological stratification of the lithosphere: Tectonophysics, v. 132, pp. 281-295.

Richter, D., 1976, Das Flysch-Stadium der Helleniden-Ein Überblick: Z. Dt. Geol. Ges., v. 127, pp. 467-483.

Rocher, M., Lacombe, O., Angelier, J., Deffontaines, B. and Verdier, F., 2000 Cenozoic folding and faulting in the south Aquitaine Basin (France): insights from combined structural and paleostress analyses: J. Struct. Geol., v. 22, pp. 627-645. 
Rowe, K.J. and Rutter, E.H., 1990, Paleostress estimation using calcite twinning: experimental calibration and application to nature: J. Struct. Geol., v. 12, pp. $1-17$.

Sibson, R.H., 1974, Frictional constraints on thrust, wrench, and normal faults: Nature, v. 249, pp. 542-544

Sibson, R.H., 1998, Brittle failure mode plots for compressional and extensional regimes: J. Struct. Geol., v. 20, pp. 655-660.

Skourlis, K. and Doutsos, T., 2003, The Pindos Fold and Thrust Belt (Greece): inversion kinematics of a passive continental margin: Int. J. Earth Sciences, v. 92, pp. 891-903.

Sotiropoulos, S., Kamberis, E., Triantaphyllou, M. and Doutsos, T., 2003, Thrust sequences at the central part of the External Hellenides: Geol. Mag., v. 140, pp. 661-668.

Tejero, R. and Ruiz, J., 2002, Thermal and mechanical structure of the central Iberian Peninsula lithosphere: Tectonophysics, v. 350, pp. 49-62.

Teufel,L.W., 1980, Strain analysis of experimental superposed deformation using calcite twin lamellae, Tectonophysics, v. 65, pp. 291-309.

Twiss, R.J., 1977, Theory and applicability of a recrystallized grain-size paleopiezometer: Pure Appl. Geophys., v. 115, pp. 227-244.

Underhill, J. R., 1989, Late Cenozoic deformation of the Hellenide foreland, western Greece: Geol. Soc. Am. Bull., v. 101, pp. 613-634

Van der Pluijm, B.A, Craddock, J.P., Graham, B.R. and Harris, J.H., 1997, Paleostress in Cratonic North America: implications for deformation of continental interiors: Science, v. 277, pp. 794-796.

Weathers, M.S., Bird, J.M., Cooper, R.F. and Kohlstedt, D.L., 1979, Differential stress determined from deformation-induced microstructures of the Moine thrust zone: J. Geophys. Res., v. 84, pp. 7495-7509.

Whitmarsh, R.B., Bott, M.H.P., Fairhead, J.D. and Kuznir, N.J., eds, 1991, Tectonic stress in the lithosphere: Phil. Trans. Royal Soc. Lond., A337, pp. 194.

Wu, S., 1993, Microstructures, deformation mechanisms and strain patterns in a vertical profile, inner Appalachian fold-thrust belt, Alabama: J. Struct. Geol., v. 15 , pp. 129-144.

Xypolias, P., 2001, The rheological properties of rocks in a compressional ductile shear zone, Phyllite-Quartzite Series, Peloponnese. Bull. Geol. Soc. Greece, v. 34, pp. 353-360.

Xypolias, P. and Doutsos, T., 2000, Kinematics of rock flow in a crustal-scale shear zone: implication for the orogenic evolution of the southwestern Hellenides: Geol. Mag., v. 137, pp. 81-96.

Xypolias, P. and Koukouvelas, I., 2001, Kinematic vorticity and strain rate patterns associated with ductile extrusion in the Chelmos Shear Zone (External Hellenides, Greece): Tectonophysics, v. 338, pp. 59-77.
Paraskevas Xypolias is a research scientist at Department of Geology, University of Patras, Greece. He received a Ph.D. in Structural Geology and Tectonics from University of Patras, in 2000. His scientific activity covered several aspects of Structural Geology and Tectonics including exhumation mechanism of high-pressure rocks, rheology of the crust, paleogeography of Eastern Mediterranean region and neotectonics.

Ioannis Koukouvelas is Associate Professor of Structural Geology and Tectonics at University of Patras, Greece. He was born in 1962 and his research activity focused on field survey, earthquake geology, tectonics, hard rock geology in the Hellenides and the Canadian Appalachian.
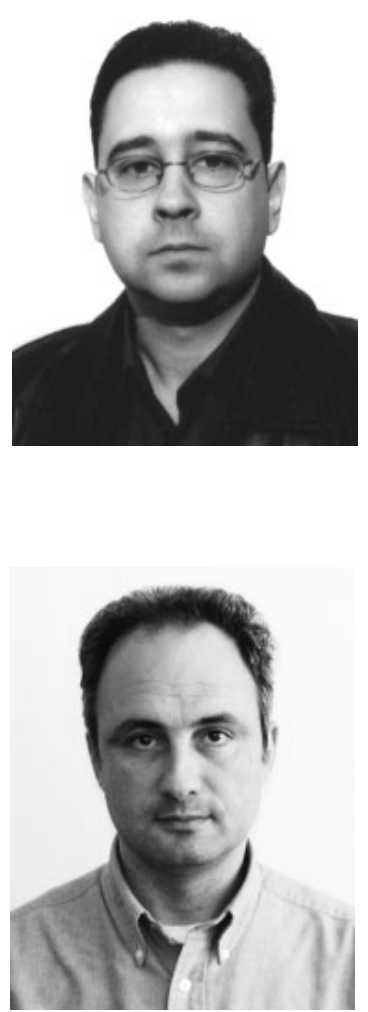

\section{Hutchison 'Young Scientist' Fund}

William Watt Hutchison, "Hutch" to his many friends around the world, was a Scots-born Canadian geologist who served Canada and the IUGS in myriad dynamic and creative ways. Most notably, he served as the IUGS Secretary General (1976-1980) at a pivotal time in its history, and as IUGS President (1984-1987). The same boundless energy, enthusiasm, skill in communications, and ability to foster teamwork that characterized his work with the IUGS also carried him to preeminent scientific administrative positions in the Canadian Government, where he served as Director General of the Geological Survey of Canada and as Assistant Deputy Minister of Earth Sciences. His distinguished career was terminated in 1987 by his untimely death at the age of 52, following a painful struggle with cancer.

One of Hutch's last wishes was to establish under IUGS auspices a memorial foundation intended to promote the professional growth of deserving, meritorious young scientists from around the world by supporting their participation in important IUGS-sponsored conferences. The first 3 beneficiaries of the Hutchison "Young Scientist" Foundation attended the 28th International Geological Congress (IGC) in Washington, D.C., in 1989.

Initially, earned interest on the funds available to the Hutchison Foundation were insufficient to sustain comparable grants every four years without seriously eroding the principal. For that reason, the IUGS made no grants from the Foundation for the 30th IGC (1996), preferring instead to strengthen the fund by allowing it to earn interest for a longer period of time and by appealing for donations from the international geologic community. Grants from the Foundation again supported deserving young scientists beginning with the 31st IGC (2000), and should continue for future Congresses. The IUGS would like to expand the resources of the Foundation to make it possible also to offer support to deserving young scientists to attend other important IUGS-sponsored scientific meetings. The Hutchison "Young Scientist" Foundation is a worthy cause that honors a fine, caring man and a distinguished, public-spirited scientist and administrator. The foundation also celebrates and promotes those things that gave Hutch the most professional satisfaction: geology, international scientific collaboration, and stimulating young minds.

The IUGS welcomes contributions to the Hutchison "Young Scientist" Foundation. Please send donations to:

Dr. Antonio Brambati

IUGS Treasurer

Dept. of Geological, Environmental and Marine Sci. (DiSGAM),

University of Trieste, 1-34127 Trieste, ITALY

Tel: +39040 558 2046; Fax: +39040 5582048

E-mail: brambati@univ.trieste.it

Checks in US dollars or Visa/Mastercard (please include account number and expiration date) are preferred in order to avoid the high cost of currency conversions. Residents of the U.S.A. are reminded that charitable gifts of this nature are tax deductible. 